\title{
Korelasi antara Latent Membrane Protein-1 Virus Epstein-Barr dengan P53 pada Karsinoma Nasofaring (Penelitian Lanjutan)
}

Yenita, Aswiyanti Asri

\begin{abstract}
Abstrak
Latar Belakang: Karsinoma nasofaring (KNF) merupakan tumor yang unik karena etiologi dan distribusi endemiknya. Di daerah endemik, etiologi KNF berkaitan dengan infeksi EBV. Infeksi EBV yang laten dan persisten pada KNF menunjukkan pola laten tipe II yang ditandai dengan ekspresi EBNA-1, LMP-1, 2 dan EBER. LMP-1 merupakan gen laten EBV yang pertama ditemukan yang dapat mentransformasi galur sel, merubah fenotip sel, menginduksi proliferasi dan mencegah apoptosis. Tujuan dari penelitian ini adalah mengetahui korelasi antara ekspresi LMP-1 EBV dengan ekspresi p53 pada KNF. Cara: Empat puluh sembilan slaid HE dan blok parafin dari KNF dianalisis dan dipulas secara imunohistokima dengan antibodi LMP-1 EBV dan p53. Korelasi antara ekspresi LMP-1 dengan ekspresi p53 diuji dengan menggunakan uji Korelasi Pearson. Nilai $p<0,05$ dianggap bermakna secara statistik. Hasil: Terdapatkan korelasi yang lemah antara ekspresi LMP-1 dengan ekspresi p53 $(r=0,249)$ dan berpola positif. Dari hasil uji statistik didapatkan hubungan yang tidak bermakna antara ekspresi LMP-1 dengan ekspresi p53 ( $p=0,085)$. Kesimpulan: Terdapat korelasi yang lemah antara ekspresi LMP-1 dengan ekspresi p53 pada KNF.
\end{abstract}

Kata kunci: LMP-1, Virus Epstein-Barr, p53, Karsinoma nasofaring..

\section{Abstract}

Background: Nasopharyngeal carcinoma (NPC) is a unique tumor due to its etiology and endemic distribution. In endemic region, the causes of the NPC related to EBV infection. Latent and persistent EBV infection on NPC show tipe II latent pattern which showed by EBNA-1, LMP-1, 2 and EBER expression. LMP-1 was the first EBV latent gene found to be able to transform cell lines, alter the phenotype of cells, induced proliferation and perevent apoptosis. This study aimed to know the correlation between LMP-1 and p53 expression in NPC. Method: Forty nine of NPC HE slides and paraffin blocks were analyzed, stained immunohistochemistrycally using antibody to LMP-1 EBV and p53. Correlation between LMP-1 expression and p53 expression were analyzed using Pearson's correlation test. $p$ value $<0,05$ were considered to be significant.Results: There is weak correlation between LMP-1 and p53 expression $(r=0,249)$ and it has positive pattern. From the statistical analyzed, the relationship between LMP-1 and $p 53$ expression is not significant $(p=0,085)$. Conclusion: There is weak correlation between LMP-1 and p53 expression in NPC.

Keywords: LMP-1, Epstein-Barr virus, p53, nasopharyngeal carcinoma

Affiliasi penulis : Bagian Patologi Anatomi Fakultas Kedokteran Universitas Andalas Padang.

Korespondensi : Yenita, Bagian Patologi Anatomi Fakultas Kedokteran Universitas Andalas Padang. dryenita@yahoo.com Telp: 0751-21176 Fax : 0751-22081

\section{Pendahuluan}

Karsinoma nasofaring (KNF) merupakan tumor yang unik karena etiologi dan distribusi endemiknya. ${ }^{1,2}$ Faktor etnik dan daerah juga mempengaruhi risiko penyakit. ${ }^{1}$ Insiden KNF yang berbeda secara geografis dan etnik juga berhubungan dengan virus Epstein-Barr. ${ }^{3}$ Secara gobal, diperkirakan terdapat 65.000 kasus baru dan 38.000 kematian yang disebabkan oleh penyakit ini pada tahun 2000.

Insiden kanker ini cukup jarang di beberapa negara, yakni hanya $0,6 \%$ dari semua keganasan. Insiden KNF di Amerika 1-2 kasus per 100.000 lakilaki dan 0,4 kasus per 100.000 perempuan. Namun tumor ini sangat banyak ditemukan di negara lain dan pada kelompok etnik tertentu, seperti di Cina, Asia Tenggara, Afrika Utara dan daerah Arctic. ${ }^{3-5}$ Insiden KNF tertinggi di dunia dijumpai pada penduduk daratan Cina bagian Selatan, ${ }^{2,4-6}$ khususnya suku Kanton di propinsi Guang Dong dan daerah Guangxi dengan angka mencapai lebih dari 50 per 100.000 penduduk pertahun.,

Indonesia termasuk salah satu negara dengan prevalensi penderita KNF yang termasuk tinggi di luar Cina. ${ }^{8}$ Data registrasi kanker di Indonesia berdasarkan histopatologi tahun 2003 menunjukan bahwa KNF menempati urutan pertama dari semua tumor ganas primer pada laki - laki dan urutan ke 8 pada perempuan. ${ }^{9}$

Selama periode tahun 2006-2008, dari data Laboratorium Patologi Anatomi Fakultas Kedokteran Universitas Andalas, RSUP. Dr M.Djamil Padang dan RSUD. Achmad Muchtar Bukittinggi, didapatkan 45 kasus KNF di wilayah propinsi Sumatera Barat. Dari keseluruhan KNF tersebut, proporsi KNF subtipe nonkeratinizing carcinoma (WHO-2) dan undifferentiated carcinoma (WHO-3) adalah sama banyak, yaitu masing-masing $37,8 \%{ }^{10}$

Karsinoma nasofaring lebih sering pada lakilaki dibanding perempuan. ${ }^{3-5}$ Kanker ini dapat mengenai semua umur dengan insidens meningkat setelah usia 30 tahun dan mencapai puncak pada 
umur 40-60 tahun. ${ }^{3}$ Kasus KNF juga pernah dilaporkan terjadi pada anak-anak dibawah usia 15 tahun. $^{11}$ Sayang sekali tumor ganas ini tidak mempunyai gejala yang spesifik, bahkan seringkali tanpa gejala, sehingga hal ini menyebabkan keterlambatan dalam diagnosis dan terapi. Bahkan pada lebih dari $70 \%$ kasus gejala pertama berupa limfadenopati servikal, yang merupakan metastasis KNF.,5

Berdasarkan klasifikasi histologi WHO tahun 1978, KNF dibagi menjadi tiga subtipe yaitu; squamous cell carcinoma (WHO-1), nonkeratinizing carcinoma (WHO-2) dan undifferentiated carcinoma (WHO-3). ${ }^{3} \quad$ Undifferentiated carcinoma (WHO-3) merupakan subtipe histologi yang utama di daerah endemik, sementara WHO-1 jarang $(<5 \%) .^{12}$

Terdapat tiga faktor etiologi utama yang berhubungan dengan KNF yaitu infeksi EBV, kerentanan genetik dan faktor lingkungan. ${ }^{2,3,7} \mathrm{Di}$ daerah endemik, infeksi EBV terutama berkaitan dengan KNF subtipe WHO-2 dan WHO-3, sedangkan untuk subtipe WHO-1 masih menjadi perdebatan. ${ }^{2,3,11}$

Virus Epstein-Barr yang ditransmisikan melalui saliva yang terinfeksi ke tempat pertama infeksinya, yaitu sel-sel epitel orofaring akan memasuki sel, bersifat menetap (persisten), tersembunyi (laten) dan sepanjang masa (long life). Hal ini membuat sel yang terinfeksi menjadi immortal melalui induksi transformasi pertumbuhan yang permanen. $^{14}$

Infeksi EBV yang laten dan persisten tersebut pada KNF menunjukkan pola laten tipe II yang ditandai dengan ekspresi EBV nuclear antigen (EBNA) -1, latent membrane protein (LMP) -1, 2 dan EBVencoded RNA (EBER). ${ }^{3,15}$ LMP-1 merupakan gen laten EBV yang pertama ditemukan yang dapat mentransformasi galur sel dan merubah fenotip sel karena potensial onkogeniknya. ${ }^{15}$ LMP-1 merupakan onkogen virus yang mirip reseptor permukaan sel yang dapat mencegah sel yang terinfeksi EBV dari apoptosis dengan menginduksi protein anti-apoptotik seperti BCL-2, A20 dan MCL-1. LMP-1 juga terlibat dalam jalur pensinyalan yang mengatur proliferasi sel dan apoptosis yaitu memicu progresifitas dan proliferasi sel melalui siklus sel (fase G1/S) dan inhibisi apoptosis. ${ }^{14,15}$

Gen p53 merupakan salah satu dari gen supresor tumor. Gen ini mendeteksi kerusakan DNA, membantu perbaikan DNA melalui penghentian fase G1 dari siklus sel dan memicu gen yang memperbaiki DNA. Sel yang mengalami kerusakan DNA dan tidak dapat diperbaiki diarahkan oleh p53 untuk mengalami apoptosis. Apabila terjadi kehilangan p53 secara homozigot, kerusakan DNA tidak dapat diperbaiki dan mutasi akan terfiksasi pada sel yang membelah sehingga sel akan mengalami transformasi keganasan. ${ }^{7}$

Gen p53 merupakan gen yang sering mengalami mutasi pada tumor manusia. Hampir lebih dari $50 \%$ tumor pada manusia mengandung mutasi gen ini. ${ }^{7,16}$ Fungsi gen p53 dapat diinaktivasi oleh berbagai mekanisme, diantaranya oleh beberapa virus DNA tertentu. Salah satu virus DNA tersebut mungkin EBV. Virus Epstein-Barr dapat mengikat protein p53 normal dan menghilangkan fungsi protektifnya. ${ }^{7}$ Penelitian imunohistokimia memperlihatkan bahwa infeksi EBV pada KNF berhubungan dengan akumulasi protein p53, bukan dengan protein BCL-2. Namun penelitian lain menyimpulkan bahwa EBV merupakan faktor etiologi yang penting yang mungkin melibatkan over ekspresi p53 dan BCL-2. ${ }^{16}$

Perkembangan KNF melibatkan hilangnya gen supresor tumor. Namun mekanisme inhibisi supresor tumor ini, unik pada KNF. Pada kebanyakan kanker kepala dan leher, kadar p53 yang rendah disebabkan oleh mutasi. Namun, p53 pada KNF tidak mengikuti pola klasik ini. ${ }^{17}$ Tidak adanya mutasi p53 pada KNF memberi kesan bahwa suatu protein virus dapat mengganggu fungsi p53. ${ }^{18}$ Dari suatu penelitian didapatkan bahwa sel-sel KNF mempunyai kadar p53 yang meningkat, dengan kadar LMP-1 yang tinggi berkorelasi dengan ekspresi p53 yang lebih tinggi. Mutasi p53 relatif jarang pada KNF, sehingga mayoritas p53 yang diekspresikan adalah wild type. Wild type p53 ini gagal menginduksi apoptosis pada KNF. ${ }^{17}$ Pemeriksaan ekspresi LMP-1 dan p53 bisa dilakukan secara imunohistokimia (IHK) dari jaringan tumor KNF.

Pada penelitian ini ingin dibuktikan korelasi antara ekspresi Latent Membrane Protein -1 virus Epstein-Barr dengan ekspresi p53 pada karsinoma nasofaring.

\section{Metode}

Dikumpulkan data sekunder hasil penelitian sebelumnya (Hubungan Ekspresi Latent Membrane Protein-1 Virus Epstein-Barr dengan Subtipe Karsinoma Nasofaring), yaitu berupa identitas penderita dan ekspresi LMP-1. Data untuk penelitian tersebut merupakan data sekunder pasien KNF Januari 2007 - Juni 2010 dari laboratorium PA FK. Unand, RSUP. Dr M.Djamil Padang dan RSUD. Achmad Muchtar Bukittinggi. Selanjutnya dari blok parafin yang sama dengan penelitian sebelumnya tersebut, dipotong lagi dan dilakukan pulasan imunohistokimia untuk menilai ekspresi p53.

Deparafinisasi dilakukan dengan xylol dan rehidrasi dengan alkohol. Pulasan imunohistokimia menggunakan teknik baku streptavidin-biotin dengan antibodi monoklonal p53 (Dako). Ekspresi p53 positif terlihat sebagai granula coklat pada inti sel. Kemudian dihitung jumlah sel tumor yang ekspresinya positif pada 500 sel tumor yang dibagi dalam 5 LPB (400x) Korelasi antara ekspresi LMP-1 dengan ekspresi p53 diuji dengan menggunakan uji Korelasi Pearson. Nilai $p<0,05$ dianggap bermakna secara statistik. 
Hasil

Dari 49 kasus KNF yang menjadi subjek penelitian, didapatkan karakteristik subjek sebagai berikut (Tabel 1).

Tabel 1. Karakteristik Subjek Penelitian

\begin{tabular}{ccc}
\hline Karakteristik & $\mathbf{f}$ & $\%$ \\
\hline Umur (tahun) & 4 & 8,2 \\
$11-20$ & 8 & 16,3 \\
$21-30$ & 6 & 12,2 \\
$31-40$ & 9 & 18,4 \\
$41-50$ & 8 & 36,7 \\
$51-60$ & 4 & 8,2 \\
$61-70$ & & \\
Rata-rata:43,61 $\pm 15,844$ & & \\
\hline Jenis Kelamin & 31 & 63,3 \\
Laki-laki & 18 & 36,7 \\
Perempuan &
\end{tabular}

Usia penderita KNF dengan frekuensi terbesar terdapat pada usia 51-60 tahun, yaitu 18 kasus $(36,7 \%)$ serta kelompok usia terendah terdapat pada usia 11-20 tahun dan 61-70 tahun, yaitu masingmasing 4 kasus (8,2\%). Rata-rata usia penderita 43,61 $\pm 15,844$ tahun, dengan usia terendah adalah 11 tahun dan tertinggi adalah 67 tahun. Penderita KNF lebih banyak pada laki-laki, yaitu 31 kasus $(63,3 \%)$.

Tabel 2. Distribusi Frekuensi Ekspresi LMP-1 pada KNF

\begin{tabular}{rcc}
\hline & $\mathbf{f}$ & $\%$ \\
\hline Ekspresi LMP-1 & & \\
Positif & 45 & 91,8 \\
Negatif & 4 & 8,2 \\
& & \\
\hline Total & 49 & 100,0 \\
\hline
\end{tabular}

Pada tabel 2. dapat dilihat bahwa secara imunohistokimia, umumnya didapatkan ekspresi LMP1 positif (45 kasus atau $91,8 \%$ ).

Tabel 3. Distribusi Frekuensi Ekspresi p53 pada KNF

\begin{tabular}{rll}
\hline & $\mathbf{f}$ & $\%$ \\
\hline Ekspresi p53 & & \\
Positif & 48 & 97,9 \\
Negatif & 1 & 2,1 \\
& & \\
\hline Total & 49 & 100,0 \\
\hline
\end{tabular}

Pada tabel 3. dapat dilihat bahwa secara imunohistokimia, umumnya didapatkan ekspresi p53 positif (48 kasus atau 97,9\%). Ekspresi p53 yang positif dapat dilihat pada gambar 1 .

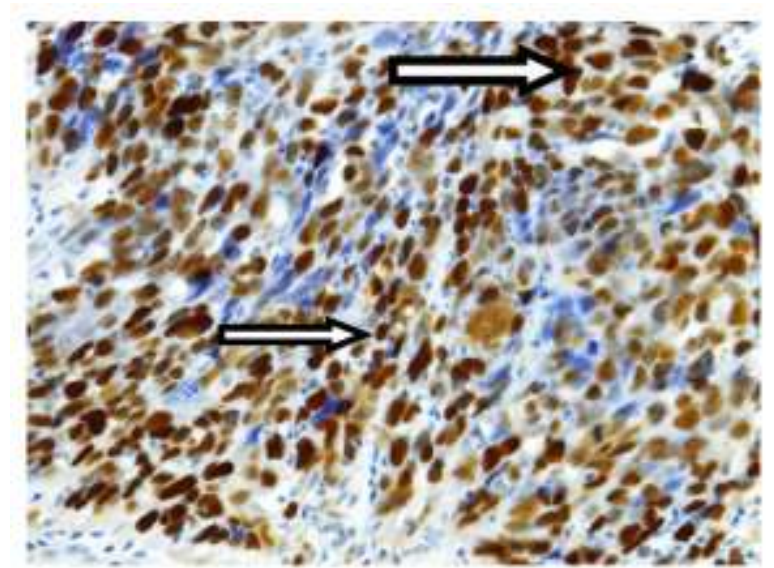

Gambar 1. Ekspresi p53 Positif (warna coklat seperti yang ditunjuk tanda panah) pada inti sel KNF (pembesaran 400x)

Korelasi antara Ekspresi LMP-1 dengan Ekspresi p53 dapat dilihat pada gambar 2. Dari gambar tersebut dapat disimpulkan bahwa korelasi antara ekspresi LMP-1 dengan ekspresi p53 menunjukkan korelasi yang lemah $(r=0,249)$ dan berpola positif. Semakin tinggi ekspresi LMP-1 semakin tinggi pula ekspresi p53nya. Hasil uji statistik didapatkan hubungan yang tidak bermakna antara ekspresi LMP-1 dengan ekspresi p53 karena nilai $p>0,05$ yaitu $p=0,085$.

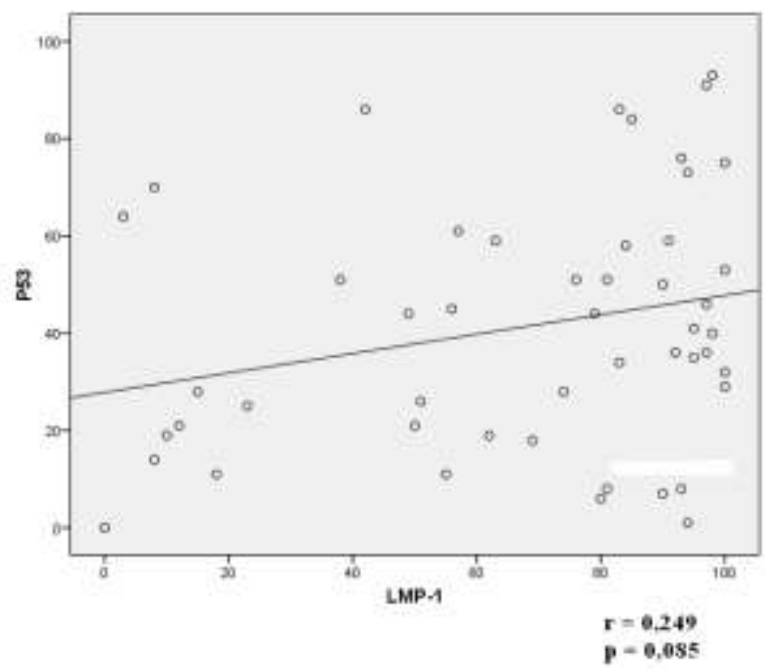

Gambar 2. Grafik Korelasi dan Regresi antara Ekspresi LMP-1 dengan Ekspresi p53

\section{Pembahasan}

\section{Karakteristik Subjek Penelitian}

Pada penelitian ini didapatkan kelompok usia terbanyak penderita KNF adalah pada usia 51-60 tahun. Usia insiden KNF yang terbanyak pada penelitian ini sesuai dengan yang didapatkan dari kepustakaan bahwa umumnya insiden KNF mencapai puncaknya pada umur 40-60 tahun., ${ }^{3,12}$ Pola distribusi usia KNF bervariasi pada berbagai daerah yang berbeda di dunia. Hirayama melaporkan bahwa 
insiden pada kedua jenis kelamin dimulai setelah usia 20-24 tahun dan stabil antara umur 45-54 tahun. Commoun et al. melaporkan usia puncak yang lebih muda di Tunisia yang merupakan daerah dengan insiden KNF menengah, yaitu 10-19 tahun disamping usia puncak 50-59 tahun. Frekuensi KNF yang relatif tinggi ini diantara populasi muda merupakan gambaran khas di area dengan insiden menengah, yaitu Uganda, Kenya, Sudan dan Tunisia. Hirayama juga melaporkan bahwa bahwa usia puncak pada remaja jarang terjadi pada suku Cina di Amerika. Balakrishnan et al. juga mengamati suatu distribusi usia bimodal dengan puncak pada kelompok umur 1524 tahun dan 45-54 tahun pada penduduk India. ${ }^{19}$

Terdapat 3 kasus KNF pada anak berusia dibawah 15 tahun (satu orang berumur 11 tahun dengan subtipe WHO-3, dua orang berumur 13 tahun, yaitu satu orang dengan subtipe $\mathrm{WHO}-1$ dan yang lain WHO-3). Penelitian KNF pada anak dibawah usia 15 tahun (suatu tinjauan retrospektif dari 65 kasus) yang dilakukan oleh Sahraoui et al., 1999, di Casablanca, didapatkan frekuensi subtipe WHO-3 sebanyak $81 \%$. $^{11}$ Peneliti lain juga pernah menemukan penderita KNF termuda yang berumur 4 tahun. ${ }^{8}$ Insiden KNF pada anak-anak mempunyai variasi yang luas tergantung pada faktor ras dan geografis.

Laki-laki merupakan penderita KNF terbanyak pada penelitian ini, dengan ratio laki-laki dan perempuan adalah 1,72:1. Hasil yang didapatkan ini tidak jauh berbeda dengan yang didapatkan dari kepustakaan bahwa KNF lebih sering pada laki-laki daripada perempuan., Lebih banyaknya penderita KNF pada laki-laki dibanding perempuan mungkin ada kaitannya dengan kebiasaan merokok pada laki-laki. Peneliti terdahulu mendapatkan bahwa orang yang merokok selama sepuluh tahun atau lebih mempunyai risiko yang tinggi terhadap $\mathrm{KNF}^{19}$ Lin et al. (dikutip dari $^{19}$ ) menemukan bahwa merokok dan bekerja pada tempat berventilasi jelek sangat kuat kaitannya dengan KNF.

Pada penelitian ini didapatkan KNF subtipe WHO-2 merupakan subtipe yang terbanyak. Di daerah endemik Cina, mayoritas KNF adalah subtipe WHO-2 dan WHO-3. Sebaliknya, di daerah non endemik seperti Amerika, WHO-1 merupakan subtipe yang terbanyak. ${ }^{12}$ Infeksi Epstein-Barr Virus berkaitan erat dengan subtipe $\mathrm{WHO}-3$ dan sebagian dengan subtipe WHO-2, namun tidak dengan subtipe WHO-1. ${ }^{13}$ Jadi kemungkinan besar infeksi EBV juga merupakan faktor risiko KNF pada penelitian ini.

\section{Ekspresi LMP-1 pada Karsinoma Nasofaring}

Pada penelitian ini, secara imunohistokimia umumnya didapatkan ekspresi LMP-1 positif, yaitu pada $91,8 \%$ kasus. Hasil ini dapat menggambarkan bahwa infeksi EBV memang merupakan faktor risiko terbesar pada kasus KNF ini, sama seperti daerah endemik lainnya. Dari kepustakaan didapatkan bahwa LMP-1 sering terdeteksi pada biopsi KNF tetapi dengan variasi yang luas diantara masing-masing tumor. Berdasarkan laporan yang terbanyak dari berbagai belahan dunia, kira-kira $50 \%-60 \%$ biopsi KNF, LMP-1 dapat divisualisasikan pada mayoritas sel-sel tumor dengan menggunakan teknik imunohistokimia. LMP-1 yang diekspresikan sangat bervariasi pada spesimen KNF diduga tidak hanya berperan dalam onkogenesis, tetapi juga dalam memelihara sifat laten virus. $^{20}$

\section{Ekspresi p53 pada Karsinoma Nasofaring}

Pada penelitian ini, secara imunohistokimia umumnya didapatkan ekspresi p53 positif, yaitu pada $97,9 \%$ kasus. Demikian juga dengan Sheu et al., ${ }^{21}$ mendeteksi 95\% protein p53 pada inti sel tumor. Hasil yang hampir sama juga didapatkan oleh Suharto dkk, ${ }^{22}$ yaitu ekspresi p53 positif pada $89,8 \%$ kasus KNF. Penelitian yang dilakukan oleh Taweevisit, ${ }^{23} \mathrm{di}$ Bangkok pada 60 kasus KNF subtipe WHO-3, mendapatkan hasil adanya overekspresi protein p53 pada $73 \%$ kasus. Hal ini menunjukkan bahwa protein p53 berkaitan erat dengan tumorigenesis KNF. Sebagian besar KNF menunjukkan overekspresi p53 dan mayoritas p53 ini merupakan wild type p53 (normal) yang mungkin merupakan respon terhadap infeksi EBV. Terekspresinya p53 secara berlebihan pada KNF tidak disebabkan oleh protein p53 jenis mutan. Beberapa laporan menunjukkan mutasi jarang terjadi pada $\mathrm{KNF}^{24}$

\section{Korelasi antara Ekspresi LMP-1 EBV dengan Ekspresi p53 pada Karsinoma Nasofaring.}

Analisis imunohistokimia spesimen KNF pada penelitian ini memperlihatkan korelasi positif antara ekspresi LMP-1 dan ekspresi p53. Hasil penelitian yang didapatkan oleh Shaoi et al., ${ }^{25}$ mengindikasikan bahwa akumulasi p53 pada KNF secara signifikan berkorelasi dengan overekspresi LMP-1.

Penelitian ini mendapatkan hasil yang sama dengan teori dari literatur yang ada, yaitu sel - sel KNF mempunyai kadar p53 yang meningkat, tingginya kadar LMP-1 berkorelasi dengan semakin tingginya ekspresi p53. ${ }^{17}$ LMP-1 menghambat pengaruh penekanan wild type p53 sehingga terjadi pertumbuhan dan progresi tumor. LMP-1 juga mampu mengalahkan hambatan pertumbuhan yang dirangsang oleh wild type p53. Disamping itu, LMP-1 dapat bekerjasama dengan p53 mutan untuk menimbulkan pertumbuhan sel-sel KNF. ${ }^{24}$

\section{Kesimpulan}

Umumnya $(91,8 \%)$ KNF mengekspresikan LMP-1 EBV. Umumnya (97,9\%) KNF mengekspresikan p53. Terdapat korelasi positif antara ekspresi LMP-1 dengan ekspresi p53, walaupun korelasi ini lemah.

\section{Daftar Pustaka}

1. Krishna SM, James S, Kattoor J, Balaram P. Serum EBV DNA as a biomarker in primary 
nasopharyngeal carcinoma of Indian origin. Jpn J Clin Oncol. 2004;34:307-11.

2. Lo KW, To KF and Huang DP. Focus on nasopharyngeal carcinoma. Cancer Cell. 2004;5:423-8.

3. Chan J.K.C, Bray F, McCarron P, Foo W, et al. Nasopharyngeal carcinoma. Dalam: Barnes L, Eveson JW, Reichart P, Sidrasky D editor. WHO classification of tumours: Pathology and genetics head and neck tumours. Lyon: IARCPress; 2005. hlm 85-97.

4. Titcomb Jr CP. High incidence of nasopharyngeal carcinoma in Asia. J Insur Med. 2001; 3:235-8.

5. Thompson L D.R. Malignant neoplasma of the nasal cavity, paranasal sinuses, and nasopharynx. Dalam: Thompson L D.R editor. Head and neck pathology. Philadelphia: Elsevier; 2006. hlm170-3.

6. Lutan R, Nasution YU. Karsinoma nasofaring. Maj Patologi Indonesia. 2002;11:34-41.

7. Kumar V, Abbas AK, Fausto N. Neoplasia . Dalam Robbin and Cotran Pathologic Basis of Disease. Edisi ke-7. Philadelphia: Elsevier Saunders; 2005. hlm 309-13.

8. Roezin A. Faktor risiko pada karsinoma nasofaring. Maj Patologi Indonesia. 2002; 11:42-5.

9. Badan Registrasi Kanker Ikatan Ahli Patologi Indonesia, Yayasan Kanker Indonesia. Data histopatologik kanker di Indonesia tahun 2003. Direktorat Jenderal Pelayan Medik Dep Kes Rl; 2003.

10. Yenita, Asri A. Studi retrospektif karsinoma nasofaring di Sumatera Barat: reevaluasi subtipe histopatologi berdasarkan klasifikasi WHO. Penelitian pendahuluan, Program Pendidikan Dokter Spesialis Patologi Anatomi Fak. Kedokteran Universitas Andalas/ Fak. Kedokteran Universitas Sumatera Utara. 2009.

11. Sahraoui S, Acharki A, Benider A, Bouras N, Kahlain A. Nasopharyngeal carcinoma in children under 15 years of age: a retrospective review of 65 pasiens. Annals of Oncology. 1999;10:1499-1502.

12. Ou S, Zell JA, Ziogas A, Culver A. Epidemiology of nasopharyngeal carcinoma in the United State: improved survival of Chinese patients within the keratinizing squamous cell carcinoma histology. Annals of Oncology. 2007;18:29-35.

13. Niedobitek G. Epstein-Barr virus infection in the pathogenesis of nasopharyngeal carcinoma. J Clin Pathol: Mol Pathol. 2000;53:248-54.

14. Infante C, Abbadessa G, Bagella L, Giardano A. Viral infection as a cause of cancer (Review). International Journal of Oncology. 2007; 30:1521-8.
15. Zheng H, Li L, Hu D, Deng X,Cao Y. Role of Epstein-Barr virus encoded Latent Membrane Protein 1 in the carcinogenesis of nasopharyngeal carcinoma. Celular \& Molecular Immunology. 2007;4(3):185-96.

16. Oyong, Hariwiyanto B, Harijadi. Expression of bcl-2 protein in nasopharyngeal carcinoma. Majalah Patologi Indonesia. 2002;11(4):1126.

17. Chou J, Lin YC, Kim J, You L, Xu Z, He B et al. Nasopharyngeal carcinoma-review of the molecular mechanisms of tumorigenesis. Head and Neck-DOI. 2008; 10.1002, July.

18. Fries KL, Miller WE, Raab-Traub N. EpsteinBarr virus Latent Membrane Protein 1 blocks p53-mediated apoptosis through the induction of A20 gene. Journal of Virology. 1996;Dec: 8653-9.

19. Kumar S. Epidemiological and etiological factors associated with nasopharyngeal carcinoma. ICMR Bulletin. 2003;33(9).

20. Khabir A, Karray H, Rodriguez $\mathrm{S}$ et al. EBV latent membrane protein 1 abundance correlates with patient age but not with metastatic behavior in north African nasopharyngeal carcinoma. Virology Journal. 2005; 2:39.

21. Sheu L, Chen A, Tseng HH, Leu FJ, Lin JK, Ho KC et al. Assesment of p53 expression in nasopharyngeal carcinoma. (Diunduh 5 Januari 2010). Tersedia dari http://www.humanpathol.com/article/00468177(95)90137-X/abstract.

22. Suharto A, Hariwiyanto $B$, Harijadi. $p 53$ and p21 WAF expressions in nasopharyngeal carcinoma in correlation with the histological type and staging. Maj Patologi Indonesia.2004;13:86-91.

23. Taweevisit M. Overexpression of P53 and neoplastic cell proliferation in undifferentiated nasopharyngeal carcinoma. Southeast Asian J Trop Med Public Health. 2007;38(1):136-40.

24. Lubis, MN. Kaitan apoptosis dengan ekspresi p-53 dan BCL-2 pada karsinoma nasofaring. Maj Patologi Indonesia. 2002;11:46-51.

25. Shaoi JY, Enbergi I, Biberfeld P, Heiden T, Zeng YX, dan Hui LF. Epstein-Barr virus LMP-1 status in relation to apoptosis, p53 expresion and leucocyte infiltration in nasopharyngeal carcinoma. (diunduh 5 Januari 2010). Tersedia dari: http://pubget.com/paper/15330177. 